\title{
АНАЛИЗ СИСТЕМЫ ОБЯЗАТЕЛЬНОГО ПЕНСИОННОГО СТРАХОВАНИЯ В РОССИЙСКОЙ ФЕДЕРАЦИИ И ЗА РУБЕЖОМ
}

\author{
(c) 2019 Никифорова Елена Владимировна
}

доктор экономических наук, профессор Департамента учета, анализа и аудита Финансовый университет при Правительстве Российской Федерации

125993, г. Москва, Ленинградский пр-т, д. 49

E-mail: EVNikiforova@fa.ru

\section{(c) 2019 Петров Александр Михайлович}

доктор экономических наук, профессор Департамента учета, анализа и аудита Финансовый университет при Правительстве Российской Федерации

125993, г. Москва, Ленинградский пр-т, д.49

E-mail:palmi@inbox.ru

\section{(C) 2019 Шерстобитова Анна Анатольевна}

кандидат экономических наук, доцент Департамента магистратуры (бизнес-программ)

Тольяттинский государственный университет

445051. Самарская область, г. Тольятти, ул. Фрунзе, 2 г.

В современных условиях в России и зарубежных странах действует система обязательного пенсионного страхования. В нашей стране выделены три уровня обеспечения: государственное, обязательное и негосударственное пенсионное обеспечение. Мировой опыт развития пенсионного страхования и социально-демографические изменения в РФ требуют, чтобы весь страховой капитал соотносился с рынком труда, а система государственного пенсионного страхования коррелировалась с планируемыми текущими и будущими демографическими изменениями в стране.

Ключевые слова: обязательное страхование, пенсионное обеспечение, пенсионная система, пенсионный возраст, пенсионные фонды, инвестиционные фонды

В Российской Федерации действует система обязательного пенсионного страхования. В соответствии с Федеральным Законом № 167, пенсионное обеспечение гарантировано всем россиянам. Выделяют следующие уровни пенсионного обеспечения в Российской Федерации:

- государственное пенсионное обеспечение, представленное следующими видами страховых пенсий: по инвалидности, старости, случаю потери кормильца и за выслугу лет;

- обязательное пенсионное страхование, представленные следующими видами пенсий по: инвалидности, случаю потери кормильца, старости;

- негосударственное пенсионное обеспечение, включающие в себя следующие виды пенсий: дополнительная, которая предполагает финансирование за счет взносов в негосударственный пенсионный фонд, пенсия, полученная от инвестирования пенсионных взносов [1].

Исследователи В.Л. Василёнок, К.Л. Мельникова отмечают, что наиболее результативной системой пенсионного страхования является солидарная пенсионная система в Германии, предполагающая, что трудоспособное население этой страны перечисляет средства из заработной платы в Пенсионный Фонд для содержания пенсионеров [5, с. 118].

Для обеспечения эффективности пенсионной системы в связи с увеличением продолжительности жизни населения в Германии и снижения динамики уровня рождаемости, руководством страны регулярно повышается размер обязательных отчислений в государственный Пенсионный Фонд.

На сегодняшний день размер таких отчислений составляет $20 \%$ от заработной платы работника. Так же следует отметить, что в проектах правительства Германии рассматривается необходимость повышения возраста выхода на пенсию с 67 лет до 70 лет.

Интересен опыт Италии, пенсионная система которой в результате многолетних и многочисленных реформ сформировалась в трехуровневую систему (рисунок 1).

Основной причиной введения второго и 


\section{ПЕНСИОННАЯ СИСТЕМА}

\section{І ый уровень}

Обязательное государственное страхование, основанное на принципе распределения. В течение трудовой жизни каждый работник отчисляет средства в обязательном порядке. Уплаченные работником в течение трудовой жизни средства, определяют сумму ежемесячной пенсии зависящей от платежей работника

\begin{tabular}{|c|c|c|c|}
\hline $\begin{array}{c}\text { Пенсия по старости, } \\
\text { выплачиваемая } \\
\text { работнику при } \\
\text { достижении } \\
\text { пенсионного возраста, } \\
\text { в случае уплаты } \\
\text { минимального } \\
\text { количество взносов } \\
\text { работником }\end{array}$ & $\begin{array}{c}\text { Пенсия по } \\
\text { выслуге лет, } \\
\text { присваиваемая } \\
\text { на основе } \\
\text { продолжительно } \\
\text { сти } \\
\text { специального } \\
\text { стажа у } \\
\text { работника }\end{array}$ & $\begin{array}{c}\text { Пенсия по } \\
\text { инвалидности, } \\
\text { выплачиваемая } \\
\text { работникам, досрочно } \\
\text { завершающим } \\
\text { трудовую } \\
\text { деятельность по } \\
\text { состоянию здоровья }\end{array}$ & $\begin{array}{c}\text { Пенсия по случаю } \\
\text { потери кормильца, } \\
\text { выплачиваемая } \\
\text { членам семьи в } \\
\text { случае смерти } \\
\text { кормильца }\end{array}$ \\
\hline
\end{tabular}

\section{ІІ ой уровень}

Дополнительная пенсия формируется исключительно за счет взносов в негосударственные пенсионные фонды, интегрирующие обязательную и дополнительную пенсию для работника в момент выхода на пенсию

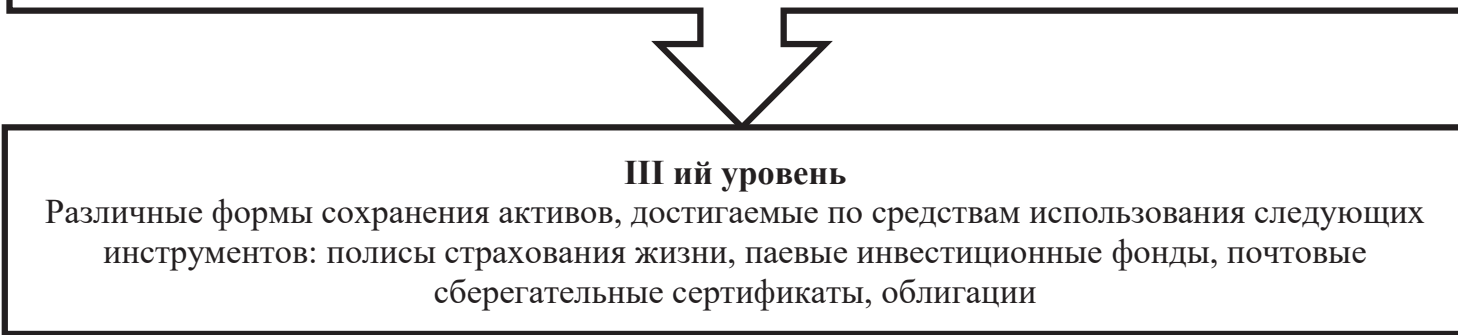

\section{Puc. 1. Иерархия пенсионной системы Италии}

третьего уровней является тенденция уменьшения коэффициента замещения заработка при получении пенсионных выплат из системы государственного пенсионного страхования, образующего первый уровень [7, с. 311, 9].

Следует отметить, что дополнительная пенсия не заменяет обязательную. Механизм ее формирования для каждого работника таков:

а) создается индивидуальный счет работника, на котором отражены поступающие взносы;

б) инвестирование средств (находящихся на счете) в финансовые инструменты: акции, облигации, долговые обязательства и т.п. Доходность размещенных средств зависит от рыночной конъюнктуры и выбора метода управления средствами.
В настоящее время граждане Италии могут стать полноправными пенсионерами в 62 года (до 2019 года период выхода на пенсию был очерчен возрастом 67 лет).

Возраст выхода на пенсию в Италии для мужчин и для женщин одинаков. Следует отметить, что ранее в 2017 году Польша снизила пенсионный возраст вопреки тенденции понижения пенсионного возраста многими государствами.

Также, интересно рассмотреть опыт пенсионной системы Соединенных Штатов Америки. Данная система состоит из двух составляющих. Первый элемент системы - это обязательное государственное страхование, при котором социальные взносы в пенсионный фонд выплачиваются работником в размере $7,65 \%$ от зарплаты и столько же уплачивает работодатель. Второй 
элемент - это добровольное частное страхование. Таким образом, при государственном страховании общий взнос в Пенсионный Фонд составляет 15,3\% [9].

Индивидуальные предприниматели оплачивают одновременно 15,3\%, предполагая, что платят за себя как за сотрудника и как работодателя. Следует отметить, что в исследуемой стране нетрудовые доходы не облагаются налогом. K таким доходам относят дивиденды, проценты по банковским вкладам и облигациям, доходы от операций с ценными бумагами, пенсионным налогом.

Несмотря на это, пенсионная система в Соединенных Штатах Америки не обеспечивает гражданам этой страны необходимый уровень жизни в пенсионном возрасте. Коэффициент замещения зарплаты пенсионными выплатами составляет около тридцати процентов, хотя достаточный уровень поддержания необходимого уровня жизни считается семьдесят или восемьдесят процентов.

С целью минимизации разрывом между доходами трудоспособного и пенсионера, в исследуемой стране функционируют добровольные пенсионные системы, дающие возможности сохранять и преумножать поступающие средства на будущую пенсию работающего сегодня человека [4, с. 21].

Необходимо подчеркнуть, что для американцев, рожденных до 1943 года, пенсионный возраст наступает в шестьдесят пять лет. Для людей, которые были рождены с 1943 г. по 1955 годы пенсионный возраст уже составляет шестьдесят шесть лет. Таким образом, пенсионный возраст постепенно увеличивается, и на данный момент времени он составляет шестьдесят семь лет для граждан Соединенных Штатов Америки, родившихся после шестидесятых годов прошлого века. Такой рост определяется из-за увеличения средней продолжительности жизни в данной стране. Подчеркнем, что все же американская Пенсионная система является гибкой, по выходу работника на пенсию, например, работающий может выйти на пенсию в и шестьдесят два года, не достигнув своего полного пенсионного возраста и получать при этом неполную пенсию.

В соответствии с отчетом Всемирной организации здравоохранения, средняя продолжительность жизни в мире все же разная. Так, рассматривая европейский континент, средняя продолжительность жизни в Германии составля- ет 83,1 года, в то время как в Италии - 82,7 года, или в России это возраст составляет 70,5 года.

В Соединенных Штатах Америки средний уровень продолжительности жизни практически больше на десять лет, чем в России и составляет 79,3 года. Такая статистика говорит о том, что Российские пенсионеры в среднем получают пенсии около десяти лет, в то время как немецкие и итальянские пенсионеры получают ее на протяжении шестнадцати лет, а американские на протяжении двенадцати лет [8].

Совершенствование системы управления обязательным пенсионным страхованием в России на основе анализа зарубежного опыта является залогом повышения эффективности управления системой обязательного пенсионного страхования в Российской Федерации.

Так, например, исследователь Т.С. Алябьева в своей работе, предлагает разработать меры, направленные:

a) на реализацию принципа трипартизма и оптимизацию механизма взаимодействия социальных партнеров при принятии решений по развитию пенсионного законодательства;

б) на функционирование обязательного пенсионного страхования и иных видов обязательного социального страхования на базе единых принципов с использованием общей информационной основы;

в) на синхронизацию обязательного пенсионного страхования с другими видами обязательного социального страхования;

г) на формирование единой системы актуарного оценивания, включая стандартизацию актуарной деятельности;

д) на совершенствование законодательства, регулирующего деятельность и правовой статус Пенсионного фонда Российской Федерации [4, с. 117].

Кроме того, в целях повышения адресности предоставления социальных гарантий и легализации теневого рынка труда необходимо совершенствование системы персонифицированного учета граждан в сфере обязательного пенсионного страхования, ведение трудовой и социальной документации граждан в электронном виде.

Важное значение в обеспечении достойного уровня пенсий имеют для российской практики негосударственные пенсионные фонды: договорные пенсионные фонды; открытые пенсионные фонды; страховые полисы.

Договорные пенсионные фонды классифи- 
цируются на закрытые и открытые. Закрытые договорные пенсионные фонды, согласно российскому законодательству создаются только для соблюдения интересов отдельных категорий работников:

- частные работники, принадлежащие к одной и той же договорной категории, одной и той же компании или группы компаний, к одной территории;

- государственные служащие, которые принадлежат к конкретным секторам;

- члены семьи работника, если это предусмотрено в уставе фонда;

- частные фрилансеры и предприниматели, занимающиеся определенной деятельностью;

- члены кооперативов работников [2, 9].
Открытые пенсионные фонды также выступают источником дополнительной пенсии для заинтересованных лиц. Особенностью открытых пенсионных фондов является непосредственное управление ресурсами, поступающими на счет фонда, банками, компаниями по управлению активами, брокерскими и страховыми компаниями, создающими открытые пенсионные фонды.

В заключении хотелось бы отметить, что в практике обязательного пенсионного страхования Российской Федерации имеются инструменты, позволяющие построить качественную систему обязательного пенсионного страхования. Тем не менее, элементы такой системы должны постоянно уточняться в соответствии с тенденцией развития делового мирового пространства.

\section{Библиографический список}

1. Федеральный закон «Об обязательном пенсионном страховании в Российской Федерации» от 15.12 .2001 N167-Ф3 (в редакции от 11.12.2018)

2. Федеральный закон «О гарантировании прав застрахованных лиц в системе обязательного пенсионного страхования Российской Федерации при формировании и инвестировании средств пенсионных накоплений, установлении и осуществлении выплат за счет средств пенсионных накоплений» от 28.12.2013 N422Ф3 (в редакции от 03.08.2018 г)

3. Федеральный закон «О страховых пенсиях» от 28.12.2013 N400-Ф3

4. Алябьева Т.С. Особенности пенсионного обеспечения зарубежных стран // Символ науки. 2017. № 4. С. 21 24

5. Василенок В. Л., Мельников К.С. Зарубежный опыт пенсионного обеспечения и реформирование пенсионной системы РФ // Экономика и экологический менеджмент. 2015. № 2. С.117-119.

6. Ефимова Л.А. Возможности и ограничения использования зарубежного опыта в процессе реформирования пенсионной системы РФ // Экономический анализ: теория и практика. 2014. № 24. С. 53.

7. Шермухамедова Ш.А. Пенсионные системы зарубежных стран // Инновационные технологии в науке и образовании. 2016. № 3. С. 309-311

8. https://www.who.int/ru.

9. Умярова Г.З. Зарубежный опыт функционирования пенсионной системы/Вектор экономики. 2017. № 11(17). C.59.

10. Петров А.М. Международные стандарты финансовой отчетности: учебник. Москва. 2019.

11. Петров А. М. Современные концепции бухгалтерского учета и отчетности: учебник. Москва. 2018.

12. Бабаев Ю.А., Петров А.М. Расчеты организации: учет, контроль и налогообложение: учебно-практическое пособие для студентов высших учебных заведений, обучающихся по специальности 080109 «Бухгалтерский учет, анализ и аудит». Москва. 2010.

13. Петров А.М., Мельникова Л.А. Затраты и расходы в системе бухгалтерского учета и налогообложения // Проблемы современной экономики. 2013. № 4 (48). С. 179-183.

14. Петров А.М. Организационный механизм контроля за движением дебиторской и кредиторской задолженности //Экономический анализ: теория и практика. 2006. № 18 (75). С. 54-62.

15. Бабаев Ю.А., Петров А.М. Бухгалтерский учет и контроль дебиторской и кредиторской задолженности. учеб. практ. пособие. Москва. 2004.

16. Бабаев Ю.А. Теория бухгалтерского учета. учебник / Ю.А. Бабаев, А.М. Петров; под ред. Ю.А. Бабаева. Москва, 2011. (Изд. 5-е, перераб. и доп.)

17. Никифорова Е.В., Вокина Е.Б., Бердникова Л.Ф. Методические аспекты стратегического анализа в определении устойчивого развития организации // Актуальні проблеми економіки. 2015. Т. 166. № 4. С. 44-50.

18. Nikiforova E. V. Paradigm of public reporting of economic entities // World Applied Sciences Journal. 2014 . T. 29. № 5. C. 667-670. 
19. Karpova T.P., Petrov A.M., Antonova O. V. Directions of Accounting Development in the Conditions of Digitalization // Jour of Adv Research in Dynamical \& Control Systems, Vol. 10, 07-Special Issue, 2018, pp.(117-125)

20. Lymar, M.P., Kevorkova, Z.A., Petrov, A.M. The convergence of national and international accounting standards: Chinese experience // International Journal of Civil Engineering and Technology. Volume 9, Issue 13, December 2018, Pages 82-94.

Поступила в редакцию 15.01.2019 